\title{
Compact Solid-State Marx Generator for Repetitive Applications
}

\author{
Neelam S. Pinjari \\ Electrical Engineering Department \\ Fr. Conceicao Rodrigues Institute of Technology \\ Navi Mumbai, India \\ neelam.pinjari@gmail.com
}

\author{
S. Bindu \\ Electrical Engineering Department \\ Fr. Conceicao Rodrigues Institute of Technology \\ Navi Mumbai, India \\ bindubalu1970@gmail.com
}

\begin{abstract}
The Marx generator plays a vital role in a pulsed power system. In this paper, a modified compact bipolar output pulse solid-state Marx generator topology is developed. A three-stage prototype is designed and tested, in which pulse width, polarity, and peak voltage of the output pulse are made variable. It is possible to generate either positive or negative pulses with less rise time. Various components which affect the repetitive frequency of the developed Marx generator are evaluated. Analysis reveals that the total time period $T_{O}$ is a function of capacitor charging time. This is been validated experimentally by operating the Marx generator for different pulse repetition frequencies. The type of charging method solely controls the charging time of the capacitor and hence the repetition frequency.
\end{abstract}

Keywords-capacitor; monopolar topology; pulse repetitive frequency; bipolar topology; charging time; high voltage time; $\mathrm{H}$ bridge circuit

\section{INTRODUCTION}

Pulse power technology is the discipline in which, the energy is accumulated over a period in a medium and is released into the load to generate a high voltage pulse instantaneously. It has many applications in fusion research, high power pulsed lasers, air pollution control, food processing, etc. [1-2]. In conventional Marx generators, the repetitiveness of the Marx generator is limited by switches and the charging method used. Recovery characteristics of the gas medium used in a spark gap switch put limitations in the repetitive rate of conventional Marx generators. The capacitor charging rate from a given power supply depends upon the charging method used. With the development of solid-state semiconductor technology, solid-state switches with high voltage blocking capacity were used to construct the solid-state Marx generator [3-4]. The gate control in solid-state switches facilitates the flexibility in output pulse amplitude, pulse width, and repetition rates. Several solid-state Marx topologies, either monopolar or bipolar, with multiple switches for charging and discharging are available in the literature [8-12]. Authors in [3] proposed a compact monopolar pulsed power generator using solid-state devices widely used in Plasma Source Ion Implantation (PSII). However, in this topology, high return current flows through the DC source during the erection mode [3]. Authors in [5] have developed a generalized solid-state Marx modulator topology wherein, multiple charging paths were used to reduce the stresses on the switches. The five-switch topology proposed in [6] has more stresses on switches, as the same switches are repeatedly being used for discharging operations.

The major limitations of the topologies used for developing bipolar output pulse are the number of switches per stage. This limitation was eliminated in [7]. The authors proposed a high voltage solid-state bipolar rectangular pulse modulator having an H-bridge circuit across the load. Each stage comprises of switch, inductor, diode, and capacitor. Stage inductors help boosting the output voltage. However, the rise time of the output pulse increases due to the inductor. In the recent years, there has been a remarkable innovation in high voltage application in the field of food technology [13-14]. In this paper, the topology proposed in [3] is converted to bipolar by including an $\mathrm{H}$-bridge circuit across the load. Per stage inductance is eliminated. The output pulse rise time of the circuit is much lower as compared to the output pulse generated by the topology proposed in [7]. Marx grounding is provided through a high resistance to reduce the source current while in erection. This type of grounding protects the source from high return current pulses and improves the output pulse wave shape. A theoretical method is developed for the determination of the repetitive frequency of a solid- state bipolar output pulse Marx generator and it is validated from the modified topology. The influence of various elements on repetitive frequency is analysed and the key parameters are identified.

\section{THE TOPOLOGY OF THE MODIFIED MARX GENERATOR}

The working of the Marx generator in bipolar mode is illustrated in Figure 1. The basic principle of the Marx generator topologies is that, all the capacitors for ' $n$ ' stages are charged to the input dc voltage magnitude in parallel through a charging element which can be a resistance, a combination of resistance and inductor or through an input switch and discharged in series into the load through the switches synchronously [3-5]. The Solid-State Marx (SSM) generator developed in [3] is modified to develop the bipolar output pulse topology. The circuit shown in Figure 1(a) is the modified bipolar topology where in a section composed of four switches in the H-configuration is included at the load sides [7]. Figure 1(b) shows the elements of an individual cell. It comprises of two diodes $D_{1}$ and $D_{1}^{\prime}$, an IGBT switch and a stage capacitor 
$C_{1}$. All capacitors are charged to the source voltage through the charging element and stage diodes. For first section it is $D_{1}$ and $D_{1}^{\prime}$. The bipolar pulses are obtained by switching alternately the pair of H-section switches. Once the capacitors are charged, switches 1 and $2^{\prime}$ of $\mathrm{H}$ configuration are triggered along with Marx switches to generate positive output pulses. A dead band is followed after this operation, which allows the capacitor to charge again. Negative pulses are obtained by switching 2 and $1^{\prime}$ of $\mathrm{H}$ configuration along with the Marx switches. Every positive and negative pulse is followed by a dead band, to prepare the capacitor for the next discharging. It is also possible to generate either positive or negative pulses. The time taken for the capacitor to charge depends upon the charging method adopted, hence it is directly related to the repetitive frequency.

(a)

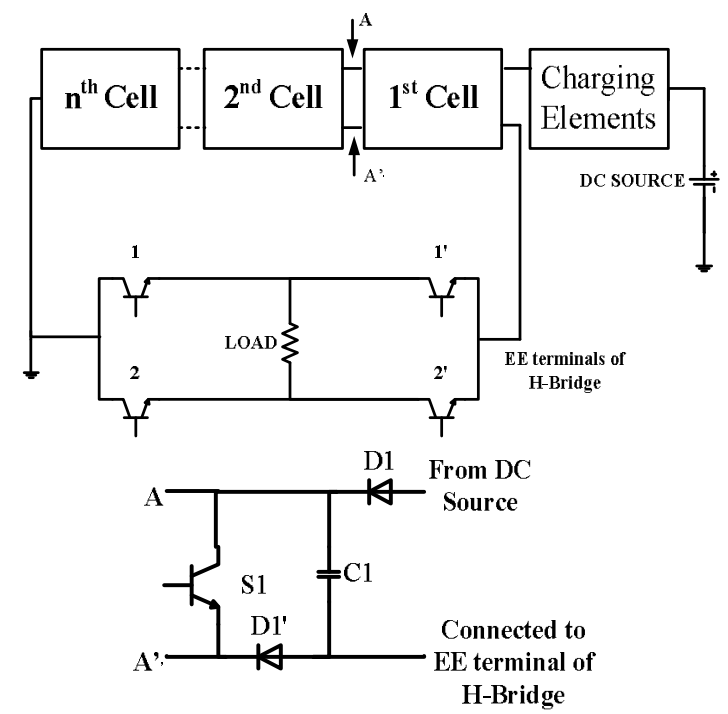

Fig. 1. (a) Modified Marx generator topology for $\mathrm{n}$ cell configuration, (b) individual cell components comprising of capacitor, diodes and IGBT for the $1^{\text {st }}$ cell.

An interesting fact about this H-bridge topology is that each diagonal pair of switches is made ON along with the Marx switches, reducing the switching losses, loading of the switches and hence, avoiding shoot-through faults in the switches of the same limb.

\section{REPETITIVE FREQUENCY EVALUATION FOR A SOLID- STATE MARX GENERATOR}

The total time $T_{O}$ required to obtain the repetitive pulses across the load is the summation of charging time of Marx capacitors $\left(t_{c h}\right)$, high voltage time $\left(t_{h v}\right)$, and switch recovery time $\left(t_{s w r}\right)$ as shown in (1). Equation (2) depicts the repetitive frequency $\left(f_{o}\right)$ which is the reciprocal of total time period.

$$
\begin{gathered}
T_{O}=t_{c h}+t_{h v}+t_{s w r} \\
f_{o}=\frac{1}{T_{O}}
\end{gathered}
$$

\section{A. Charging Time $\left(t_{c h}\right)$}

Marx charging time $\left(t_{c h}\right)$ mainly depends on the charging method used. The rating of the charging element is decided based on the limitation of the charging currents. The equivalent Marx with a resistive (R) charging method circuit is shown in Figure 2 [15]. The capacitors in all the stages are charged through intermittent diodes in the modulator. It is assumed that all stage capacitances take the same time to charge to the supply voltage. The time required for Marx capacitors to charge to the input voltage is given by (3).

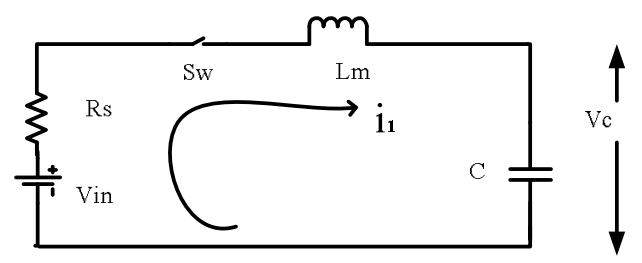

Fig. 2. Equivalent circuit of solid-state Marx while charging [1, 2].

$$
t_{c h}=\tau * \ln \left[1-\frac{V_{c}}{V_{i n}}\right]
$$

where $R_{S}$ is the charging resistance $(\Omega), L_{m}$ is the Marx inductance $(\mathrm{nH}), C$ is the Marx stage capacitance $(\mu \mathrm{F}), \tau$ is the charging time constant $\left(R_{s} C\right), t_{c h}$ the charging time $(\mu \mathrm{s}), V_{c}$ is the Voltage across the Marx per stage capacitance $C(\mathrm{~V})$, and $V_{\text {in }}$ is the input Voltage (V).

\section{B. High Voltage Time $\left(t_{h v}\right)$}

High voltage time $\left(t_{h v}\right)$ is calculated from (4). It is composed of two-time parameters, erection time $\left(t_{e r}\right)$ and discharging time $\left(t_{d i s}\right)$.

$$
t_{h v}=t_{e r}+t_{d i s}
$$

The switch erection time $\left(t_{\text {ersw }}\right)$ for an IGBT is composed of two parts, propagation delay time (turn-on delay time $t d_{o n}$ ) and the sum of input transition rise time along with collector current rise time $\left(t_{r}\right)$ respectively:

$$
\text { Switch Erection Time }\left(t_{\text {ersw }}\right)=t d_{\text {on }}+t_{r}
$$

The trigger signal initiated from the controller is further sent through buffer and driver circuits to trigger the IGBT switches. Thus, the individual propagation delay time for the above components must be considered in the calculations of $t_{e r}$. Buffer erection time is the summation of propagation delay $(\mathrm{ON})$ time $t_{p d}$ and input transition (rise) time $t_{t}$ as shown in (6):

$$
\text { Buffer Erection Time }=t_{p d}+t_{t}
$$

Driver erection time is illustrated in (7) which is the summation of propagation delay time to high output level $t_{P L H}$ and rise time $t_{r d}$.

$$
\text { Driver Erection Time }=t_{P L H}+t_{r d}
$$

The total $t_{e r}$ time is evaluated by:

$$
t_{\text {er }}=\text { Switch Erection Time }(I G B T)+
$$

Buffer Erection Time + Driver Erection Time

The discharging time $\left(t_{d i s}\right)$ is considered from the instant of switching into the load until the load voltage decreases to a 
minimum magnitude compared to peak output voltage $V_{O}$. The Marx discharging circuit is shown in Figure 3.

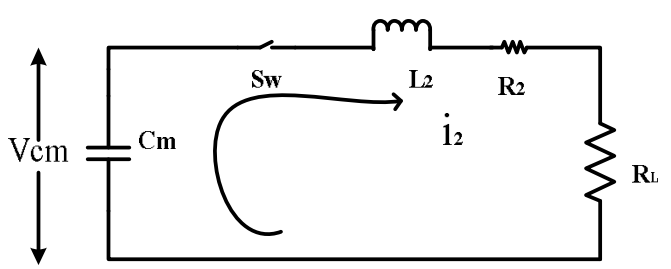

Fig. 3. Equivalent circuit of solid-state Marx while discharging.

The time required for the Marx capacitors to discharge into the load, $t_{d i s}$, is given by (9).

$$
\begin{gathered}
\mathrm{t}_{d i s}=-\frac{1}{\mathrm{~A}} \ln \left[\frac{V_{c m}-\left(R_{2}+R_{L}\right) \mathrm{i}_{2}}{V_{c m}}\right] \\
\mathrm{A}=\frac{R_{2}+R_{L}}{L_{2}} \quad \text { (10) }
\end{gathered}
$$

where $V_{c m}$ is the Voltage across the Marx equivalent capacitance $C_{m}(\mathrm{~V}), L_{2}$ is the Marx inductance $(\mathrm{nH}), i_{2}$ is the loop current (A), $R_{2}$ is the equivalent series resistance of capacitor $(\Omega), R_{L}$ is the load resistance $(\Omega)$, and $\mathrm{A}$ is a constant depending on circuit parameters.

\section{Switch Recovery Time $\left(t_{\text {swr }}\right)$}

Every output pulse is followed by a dead band where the capacitor is preparing or charging for the next cycle. During this time the Marx switches are OFF. Hence, it is essential to consider the recovery time of buffer and driver ICs in the calculation of $t_{s w r}$. Normally, solid-state switches (SSS) have nanosecond turn-on, turn-off, and switch recovery time $\left(t_{s w r}\right)$. IGBT recovery time $\left(t_{I G B T}\right)$ is the summation of the turn-off delay time $\left(t d_{o f f}\right)$ and the fall time $\left(t_{f}\right)$ :

$$
\text { IGBT Recovery Time }\left(t_{I G B T}\right)=t d_{o f f}+t_{f}
$$

Buffer recovery time is the summation of the propagation delay (OFF) time $\left(t_{p d f}\right)$ and the input transition fall time $\left(t_{t f}\right)$ :

$$
\text { Buffer Recovery Time }=t_{p d f}+t_{t f}
$$

The recovery time required for the driver IC given in (13) is the summation of the propagation delay time to low output level $\left(t_{P H L}\right)$ and the fall time $\left(t_{f d}\right)$ :

$$
\text { Driver Recovery Time }=t_{P H L}+t_{f d}
$$

Total switch recovery time $\left(t_{s w r}\right)$ is given in (14):

$$
\begin{gathered}
t_{s w r}=I G B T \text { Recovery Time } \\
+ \text { Buffer Recovery Time }+ \text { Driver Recovery Time }
\end{gathered}
$$

The minimum dead band required is the time taken by the capacitor to charge for the next section, which is $t_{c h}$. This dead band time is equal to the $t_{O F F}$ period as shown in Figure 4.

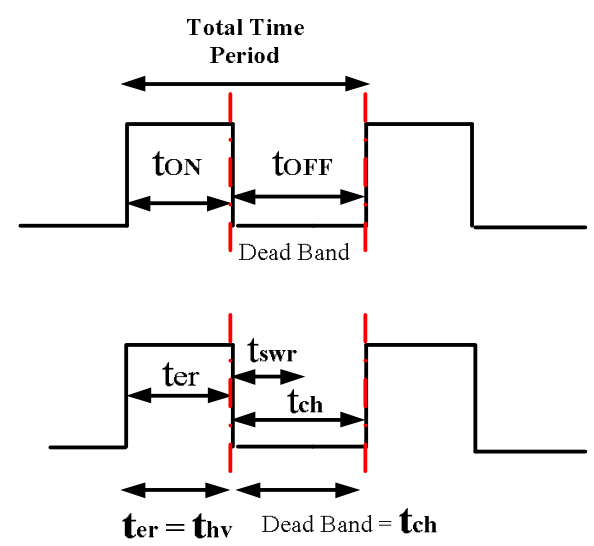

Fig. 4. Switching sequence for Marx generator.

\section{DESIGN AND HARDWARE IMPLEMENTATION OF THE MARX GENERATOR WITH BIPOLAR OUTPUT}

The three stage modified bipolar topology was designed, implemented, and tested. The circuit is designed for $1000 \mathrm{~V}$ input voltage, $110 \mathrm{~Hz}$ switching frequency, $10 \%$ voltage droop and $14 \mu \mathrm{s}$ pulse width. IGBT switches of $1700 \mathrm{~V}, 32 \mathrm{~A}$ IXGH32N170A were used for the Marx generator and $\mathrm{H}-$ bridge configuration. Diodes with ratings of $1200 \mathrm{~V}, 30 \mathrm{~A}$, RHR30120 were considered. Per stage, the capacitor rating is $1 \mu \mathrm{F}, 1000 \mathrm{~V}$ [4]. HCPL3120 drivers and SN74NC573N buffer ICs were used for triggering the IGBTs. The trigger signals were initiated by the LPC214X series ARM7 controller. The load is a resistive one with $1000 \Omega$ resistance. The resistive charging method was used for testing. The selected resistance value was $100 \Omega$. DC auxiliary power supply of $5 \mathrm{~V}$ and $15 \mathrm{~V}$ was developed for the ARM7 controller, buffer, and driver ICs. A regulated DC power supply source of Aplab with ratings of $100 \mathrm{~V}, 2 \mathrm{~A}$ and Tektronix TBS1072B DSO $70 \mathrm{MHz}, 1 \mathrm{GS} / \mathrm{s}$ was used for testing.

\section{A. Experimental Setup and Testing of the Modified Marx Generator Topology}

When the circuit in Figure 1(a) is in erection, the current can flow through two alternate paths. One is through the load and the other through the ground point at (CC) and the negative terminal of the source (source ground) as shown in Figure 5(a). Eventually an indirect short circuit of the DC source is caused through the alternate grounding path. This short circuit (caused by two different potentials) produces large stresses on the DC source. The reverse current through the DC source leads to its tripping. Also, the output voltage waveform was not perfect. Tripping occurs when the $\mathrm{CC}$ voltage equals to the $\mathrm{DC}$ voltage. Hence, the input voltage for testing is restricted to lower potentials. The ringing effect is also observed in the output voltage waveform. To eliminate this problem, it is decided to control the magnitude of the reverse current flowing through the DC source. The circuit is modified by providing a ground resistance $R_{G R D}(1000 \Omega, 25 \mathrm{~W})$ as shown in Figure $5(\mathrm{~b})$. The additional ground resistance $R_{G R D}$ changes the discharging time constant of the capacitor, as $R_{G R D}$ and load resistance are now connected in parallel. $R_{G R D}$ also helps improving the wave shape for the output voltage pulses [15-16]. 
The assembled experimental setup of the modified topology is shown in Figure 6. This is tested for an input voltage of $50 \mathrm{~V}$.

(a)

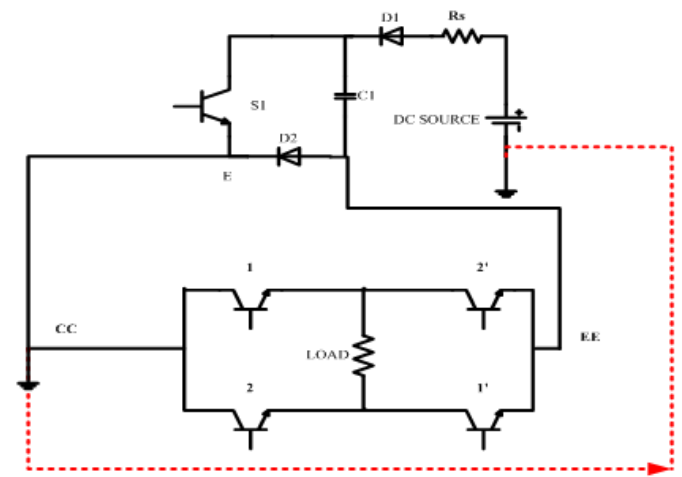

Direet $\mathrm{SC}$ between the terminals $\mathrm{CC}$ and Negative terminal of Source. (Source Ground)

(b)

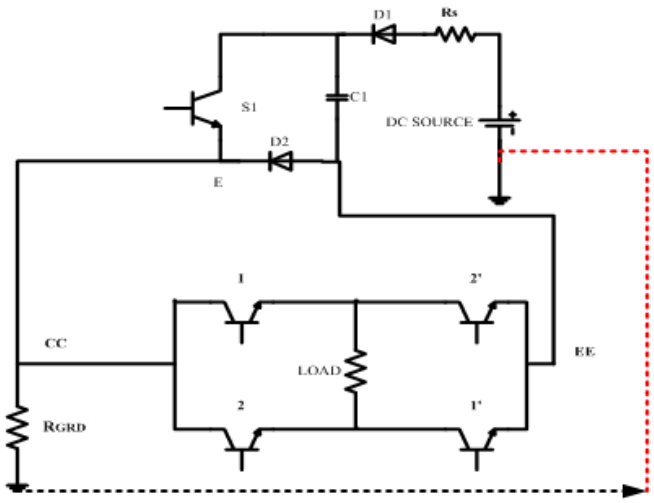

Fig. 5. Circuit connections showing the short circuit of the DC source through CC terminals.

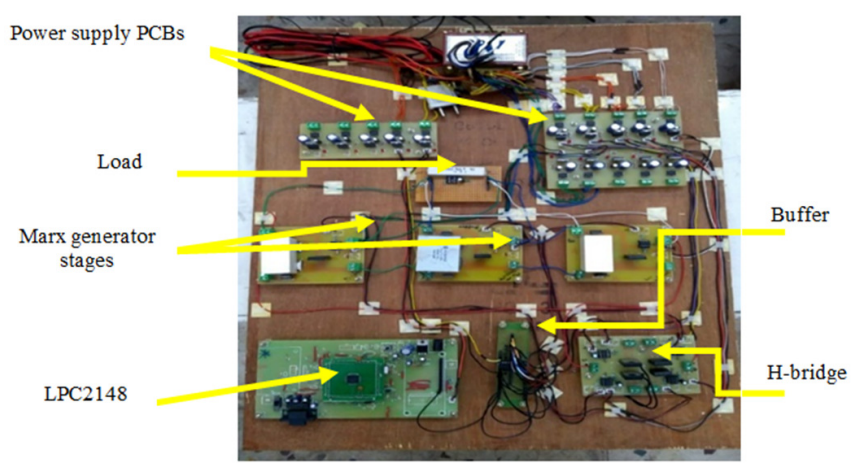

Fig. 6. Experimental setup of the prototype bipolar topology.

Figure 7(a) represents the repetitive bipolar output pulses, with $110 \mathrm{~Hz}$ repetitive frequency. Figures $7(\mathrm{~b})$ and (c) represent the positive and negative voltage pulses with a slight droop, of amplitude $140 \mathrm{~V}$ and $138 \mathrm{~V}$, respectively. The rise time of positive and negative pulse is in the range of ns. The 10 stage, $10 \mathrm{kV}$, Marx generator is modeled in Simulink and tested to find the feasibility of its performance in high voltage. Figure 7(d) illustrates the bipolar output pulses with amplitude of $9.9 \mathrm{kV}$. (a)

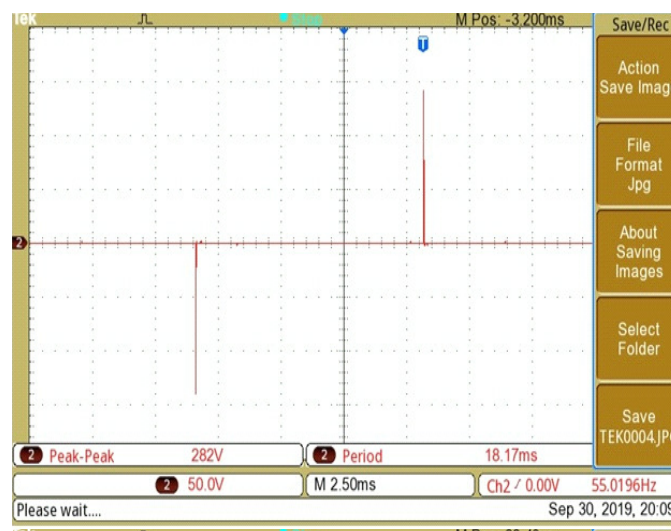

(b)

(c)
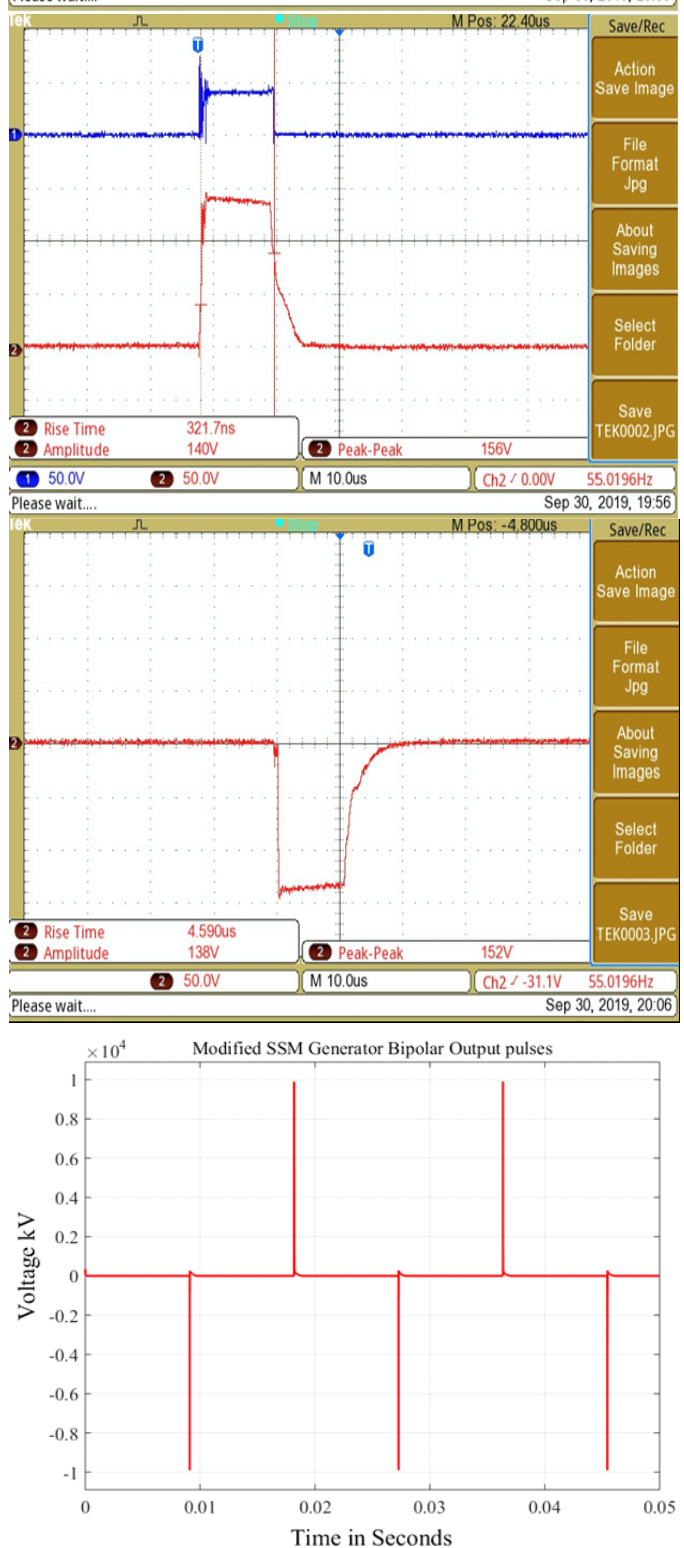

Fig. 7. (a) Repetitive bipolar output pulses (50V/division, $1 \mathrm{X}$ probe), (b) positive pulse with $140 \mathrm{~V}$ peak, along with IGBT trigger signal pulse (upper blue trace), (c) negative pulse with voltage magnitude of $138 \mathrm{~V}(50 \mathrm{~V} /$ division, $1 \mathrm{X}$ probe), and (d) $9.9 \mathrm{kV}$ output pulse of 10 stage modified topology with $1000 \mathrm{~V}$ input voltage from MATLAB simulation. 
This topology provides a flexible control to change pulse width, polarity, and output pulse magnitude. The pulse width can be made variable by changing the code of the ARM7 controller. Switching each diagonal pair of IGBTs independently gives the monopolar output pulses of either polarity. Trigger pulses to the driver input pin can be detached to prevent the inclusion of a cell, through which the output voltage across the load can be varied.

\section{B. Repetitive Frequency of a Marx Generator}

The total time period for any given Marx modulator is calculated by (1). The charging time $t_{c h}$ required for capacitors to charge is calculated as $351 \mu \mathrm{s}$ from (3). The input voltage $\left(V_{i n}\right)$, charging resistance $\left(R_{S}\right)$ and stage capacitance $(C)$ values considered are $50 \mathrm{~V}, 100 \Omega$ and $1 \mu \mathrm{F}$ respectively. Marx inductance $\left(L_{2}\right)$ is obtained from the short circuit test on the Marx generator and its value is $7.8 \mathrm{nH}$. The discharging time $t_{d i s}$ for the Marx circuit is $0.33 \mathrm{~ns}$ as per (13). The circuit parameters considered are: $V_{c m}=142 \mathrm{~V}$ is the voltage across the Marx equivalent capacitance, $L_{2}=7.8 \mathrm{nH}$, loop current $i_{2}=0.14 \mathrm{~A}$, equivalent series resistance of capacitor $R_{2}=0.1 \Omega$, and load resistance $R_{L}=1000 \Omega$. The other time components are obtained from the respective data sheets. Table I shows the detailed evaluation of time parameters essential for the calculation of $T_{O}$. As $t_{d i s}<<t_{e r}$, the $t_{h v}$ is equal to $t_{e r}$. Hence, $t_{O N}$ is equal to $t_{e r}$ as given by (15). Hence, we can state that the minimum pulse width required for a given Marx topology is its $t_{e r}$ time.

$$
t_{O N}=t_{e r}
$$

During the capacitor charging all the switches are OFF and the recovery of devices happened at this interval. From the data it can be seen that $\mathrm{t}_{\mathrm{swr}}<<\mathrm{t}_{\mathrm{ch}}$, hence the $t_{O F F}$ is equal to the charging time of capacitances $\left(t_{c h}\right)$ :

$$
t_{O F F}=t_{c h}
$$

Therefore, the total time period can be represented by:

$$
T_{O}=t_{c h}+t_{e r}
$$

Table I shows that $t_{e r}<<t_{c h}$, hence $T_{O}$ can be modified as mentioned in (18). $T_{O}$ depends on the type of charging method adopted and the value of stage capacitance [17].

$$
T_{O}=t_{c h}
$$

The repetitive frequency depends on charging time and can be improved by minimizing it. This can be attained by selecting a proper input charging method. The highest repetitive frequency for the designed monopolar Marx generator is $2.85 \mathrm{kHz}$. Figure 8 shows the detailed switching sequences of the given bipolar topology. The dead band selected is $351 \mu \mathrm{s}$. The total time of operation calculated for the generation of bipolar pulses across the load of the modified topology is given by (19):

$$
T_{O}=2\left(t_{c h}+t_{e r}\right)
$$

Bipolar Marx topology operates with half the frequency of

\begin{tabular}{|c|c|c|c|}
\hline \multicolumn{2}{|c|}{$\begin{array}{l}\text { Various time parameters concerned } \\
\text { with the computation of } T_{o}\end{array}$} & \multirow{2}{*}{$\begin{array}{c}\begin{array}{c}\text { Calculated } \\
\text { time }\end{array} \\
351 \mu \mathrm{s}\end{array}$} & \multirow{2}{*}{$\begin{array}{c}\text { Datasheet } \\
\text { specifications and } \\
\text { remarks }\end{array}$} \\
\hline Charging time & $t_{c h}$ & & \\
\hline $\begin{array}{l}\text { High Voltage } \\
\text { time } t_{h v}\end{array}$ & $=t_{e r}+t_{d i s}$ & & From (4) \\
\hline \multirow{2}{*}{$\begin{array}{l}\text { Switch erection } \\
\text { time } t_{\text {ersw }}\end{array}$} & $t d_{\text {on }}(46 \mathrm{~ns})$ & \multirow{2}{*}{$103 \mathrm{~ns}$} & \multirow{2}{*}{ From (5) at $25^{\circ} \mathrm{C}$} \\
\hline & $t_{r}(57 \mathrm{~ns})$ & & \\
\hline \multirow{2}{*}{$\begin{array}{l}\text { Buffer erection } \\
\text { time }\end{array}$} & $t_{p d}(44 \mathrm{nsec})$ & \multirow[t]{2}{*}{$59 \mathrm{~ns}$} & \multirow[t]{2}{*}{ From (6) } \\
\hline & $t_{t}(15 \mathrm{nsec})$ & & \\
\hline \multirow{2}{*}{$\begin{array}{c}\text { Driver erection } \\
\text { time }\end{array}$} & $t_{\mathrm{PLH}}(0.5 \mu \mathrm{s})$ & \multirow[t]{2}{*}{$600 \mathrm{~ns}$} & \multirow{2}{*}{$\begin{array}{c}\text { From (7) at }-40^{\circ} \mathrm{C} \text { to } \\
100^{\circ} \mathrm{C}\end{array}$} \\
\hline & $t_{r}(0.1 \mu \mathrm{s})$ & & \\
\hline$t_{\mathrm{er}}$ & \multicolumn{2}{|l|}{$762 \mathrm{~ns}$} & From $(8)$ \\
\hline Discharging time & \multirow{2}{*}{\multicolumn{2}{|c|}{$0.033 \mathrm{~ns}$}} & From (9) \\
\hline$t_{d i s}$ & & & $t_{d i s}<<t_{e r}$ \\
\hline$t_{h v}=t_{e r}$ & \multicolumn{3}{|c|}{$762 \mathrm{~ns}$} \\
\hline \multirow{2}{*}{$\begin{array}{c}\text { IGBT, buffer and } \\
\text { driver recovery } \\
\text { time } \\
\end{array}$} & & \multirow{2}{*}{$969 \mathrm{~ns}$} & From (14) \\
\hline & $t_{\mathrm{swr}}$ & & $\mathrm{t}_{\mathrm{swr}}<<\mathrm{t}_{\mathrm{ch}}$ \\
\hline \multirow{2}{*}{$\begin{array}{l}\text { IGBT recovery } \\
\text { time }\end{array}$} & $t d_{o f f}(260 \mathrm{~ns})$ & \multirow[t]{2}{*}{$310 \mathrm{~ns}$} & \multirow[t]{2}{*}{ From (11) } \\
\hline & $t_{f}(50 \mathrm{~ns})$ & & \\
\hline \multirow{2}{*}{$\begin{array}{c}\text { Buffer recovery } \\
\text { time }\end{array}$} & $t_{\mathrm{pdf}}(44 \mathrm{~ns})$ & \multirow[t]{2}{*}{$59 \mathrm{~ns}$} & \multirow[t]{2}{*}{ From (12) } \\
\hline & $t_{t f}(15 \mathrm{~ns})$ & & \\
\hline \multirow{2}{*}{$\begin{array}{c}\text { Driver recovery } \\
\text { time }\end{array}$} & $t_{\mathrm{PHL}}(0.5 \mu \mathrm{s})$ & \multirow[t]{2}{*}{$600 \mathrm{~ns}$} & \multirow[t]{2}{*}{ From (13) } \\
\hline & $t_{f d}(0.1 \mu \mathrm{s}$ & & \\
\hline
\end{tabular}
the monopolar topology. Hence, the maximum repetitive frequency obtained for the bipolar topology is $1.42 \mathrm{kHz}$.
TABLE I. TIME PARAMETERS CONCERNED WITH THE COMPUTATION OF $T_{O}$
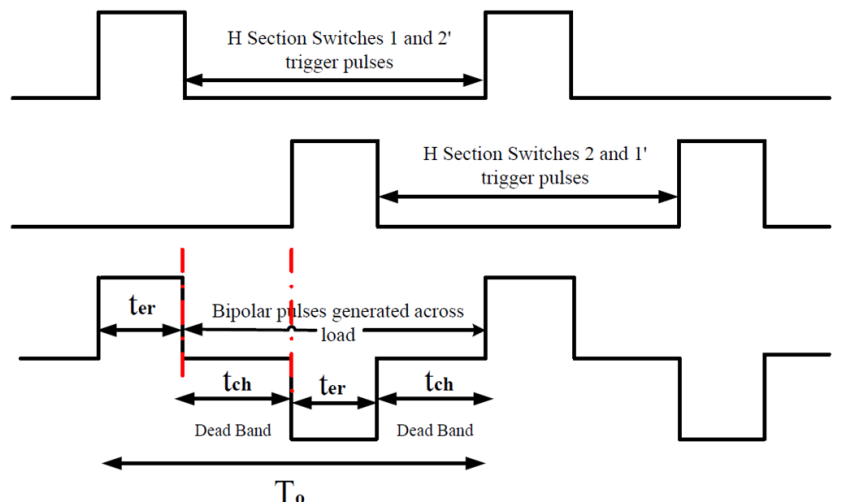

Fig. 8. Switching sequence for the bipolar topology.

C. Performance of the Modified Marx Generator Topology for Variable Pulse Repetitive Frequency (VPRF)

The modified Marx generator circuit has been tested in order to find the highest repetitive frequency possible. The total time period $T_{O}$ was calculated from (18) and was $351 \mu \mathrm{s}$. Testing was carried out for an input voltage of $80 \mathrm{~V}$, PRF of $1.42 \mathrm{kHz}$. Figures 9(a)-(b) show the pulses obtained across the load. The output pulse is $440 \mathrm{~V}$ pk-pk, with PRF $1.42 \mathrm{kHz}$. The positive pulse has a magnitude of $246 \mathrm{~V}$. The above output voltage magnitude confirms that the stage capacitances charge is to its maximum, with $t_{c h}=351 \mu \mathrm{s}$. For analysis purposes it was decided to reduce the time period $t_{c h}$ to half of the previous value, i.e. to $176 \mu$ s. Figure 9(c) shows the multiple output pulses generated at PRF $2.79 \mathrm{kHz}$. From Figure 9(d) we see that the repetitive output voltage waveforms developed across the load have a magnitude of $160 \mathrm{~V}$. This reveals that the charging of stage capacitances is reduced to nearly $66.66 \%$ at 
PRF of $2.79 \mathrm{kHz}$, keeping the input supply voltage constant. Thus, we can conclude that the charging time $t_{c h}$ decides the PRF for a Marx modulator. This time, $t_{c h}$ depends upon the type of charging method adopted. The graph in Figure 9(e) represents the variations of the output voltage against VPRFs. Analysis indicates that as the $t_{c h}$ is reduced the stage capacitors do not charge to their optimum magnitudes.

(a)

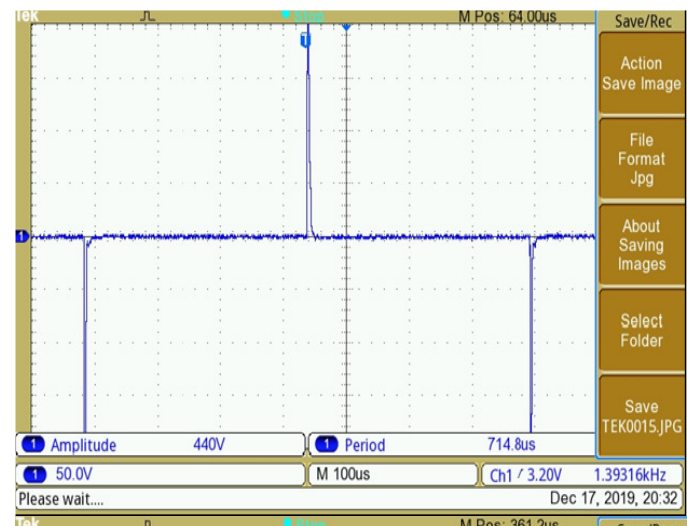

(b)

(c)

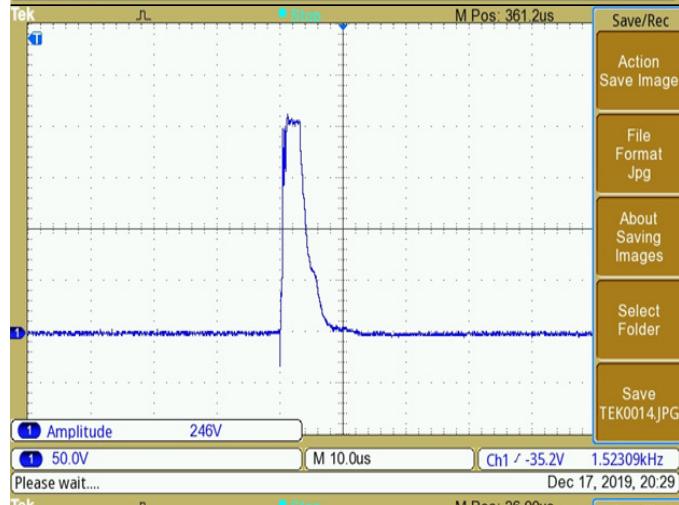

(d)
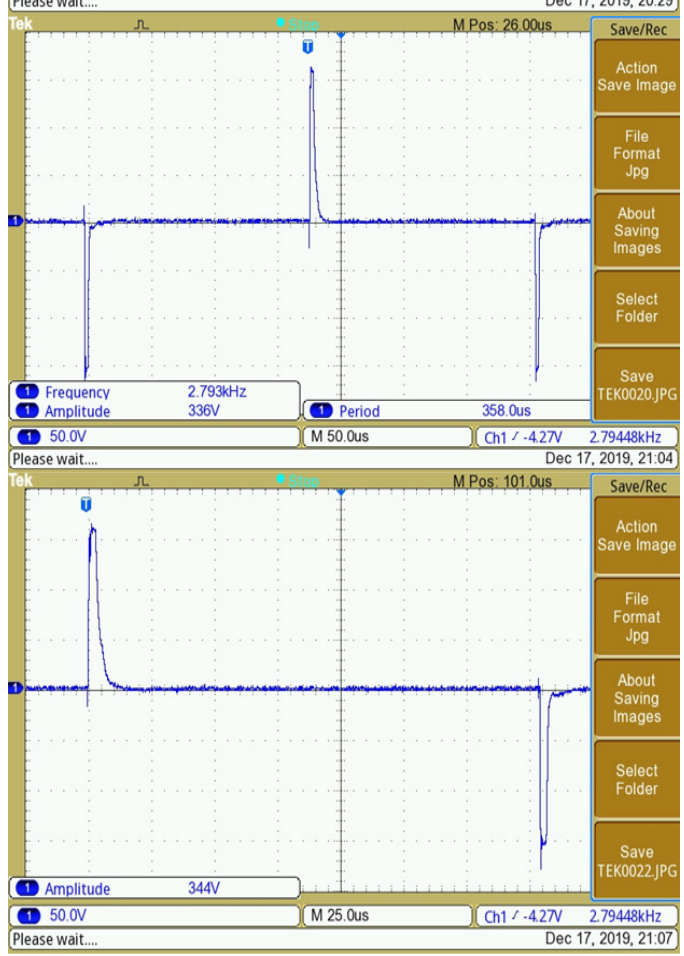

REPETITIVE FREQUENCY VS OUTPUT VOLTAGE

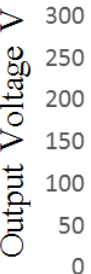

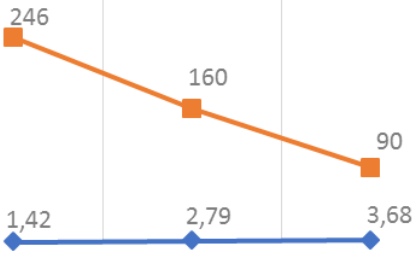

Repetitive Frequency $\mathrm{kHz}$

Fig. 9. (a) Repetitive bipolar pulses with magnitude of $220 \mathrm{~V}$ with PRF $1.42 \mathrm{kHz}$, (b) positive pulse of H-Bridge circuit with voltage magnitude of $246 \mathrm{~V}$ with $\mathrm{PRF} 1.42 \mathrm{kHz}(50 \mathrm{~V} /$ division, $1 \mathrm{X}$ probe), (c) repetitive bipolar pulses with magnitude of $160 \mathrm{~V}$ with $\mathrm{PRF} 2.79 \mathrm{kHz}$ (50V/division, $1 \mathrm{X}$ probe), (d) Bipolar pulses with magnitude of $344 \mathrm{~V}$ pk-pk with PRF $2.79 \mathrm{kHz}$ (50V/division, $1 \mathrm{X}$ probe), and (e) Graph of the Repetitive Frequency vs the Output Voltage obtained across the load for various VPRFs.

\section{CONCLUSION}

A modified bipolar output pulse Marx generator with rise and fall time in the nanosecond range was built and tested for low Voltage. The design is flexible to generate output pulse with variable pulse width, polarity, and peak voltage. It is also able to generate either positive or negative pulses. The absence of stage inductance improves the output pulse rise time. Therefore, we succeeded in building a simple Marx generator with optimum number of switching devices which can generate flexible output pulse with lowest rise time. Equations showing the repetitive frequency for the Marx generator were developed. It is found that the limiting factor for repetitive operation in solid-state Marx generator is only the capacitor charging time, since all the other time parameters are negligible compared to it. Hence, the type of charging method adopted decides the repetitive frequency for SSM generators. Feasibility of modified SSM generator in high voltage was checked with MATLAB Simulink.

For higher voltage applications, additional higher rating switches are required in bipolar topologies. Thus, a single switch in H-bridge will not be capable to withstand the high voltages.

\section{REFERENCES}

[1] M. Dimitropoulou, D. Pylarinos, K. Siderakis, E. Thalassinakis and M. Danikas, "Comparative Investigation of Pollution Accumulation and Natural Cleaning for Different HV Insulators", Engineering, Technology \& Applied Science Research, vol. 5, no. 2, pp. 764-774, April 2015.

[2] G. Melissinos and M. G. Danikas, "On Polymers Nanocomposites: Electrical Treeing, Breakdown models and Related Simulations", Engineering, Technology \& Applied Science Research, vol. 8, no. 2, pp. 2627-2632, April 2018.

[3] Y. Wu, K. Liu, J. Qiu, X. Liu, and H. Xiao, "Repetitive and High Voltage Marx Generator Using Solid-state Devices," IEEE Transactions on Dielectrics and Electrical Insulation, vol. 14, no. 4, pp. 937-940, Aug. 2007, doi: 10.1109/TDEI.2007.4286529.

[4] L. Gao, K. Liu, J. Qiu, and D. Wang, "All solid-state Marx modulator with bipolar high-voltage fast narrow pulses output," in 2010 IEEE International Power Modulator and High Voltage Conference, May 2010, pp. 373-376, doi: 10.1109/IPMHVC.2010.5958371.

[5] L. M. Redondo, H. Canacsinh, and J. F. Silva, "Generalized solid-state marx modulator topology," IEEE Transactions on Dielectrics and 
Electrical Insulation, vol. 16, no. 4, pp. 1037-1042, Aug. 2009, doi: 10.1109/TDEI.2009.5211851.

[6] H. Canacsinh, L. M. Redondo, J. F. Silva, and E. Schamiloglu, "SolidState Bipolar Marx Modulator Modeling," IEEE Transactions on Plasma Science, vol. 42, no. 10, pp. 3048-3056, Oct. 2014, doi: 10.1109/TPS.2014.2337716.

[7] A. Kwasinski et al., "Bipolar Solid State Marx Generator," US 2011/0065161 A1, Mar. 17, 2011.

[8] K. Liu, Y. Luo, and J. Qiu, "A Repetitive High Voltage Pulse Adder Based on Solid State Switches," IEEE Transactions on Dielectrics and Electrical Insulation, vol. 16, no. 4, pp. 1076-1080, Aug. 2009, doi: 10.1109/TDEI.2009.5211857.

[9] R. L. Cassel, "An all Solid State Pulsed Marx Type Modulator for Magnetrons and Klystrons," in 2005 IEEE Pulsed Power Conference, Jun. 2005, pp. 836-838, doi: 10.1109/PPC.2005.300791.

[10] S. Zabihi, Z. Zabihi, and F. Zare, "A solid state Marx generator with a novel configuration," in 2011 19th Iranian Conference on Electrical Engineering, May 2011, pp. 1-1, doi: 10.1109/TPS.2011.2155102.

[11] J. Pelletier and A. Anders, "Plasma-based ion implantation and deposition: a review of physics, technology, and applications," IEEE Transactions on Plasma Science, vol. 33, no. 6, pp. 1944-1959, Dec. 2005, doi: 10.1109/TPS.2005.860079.

[12] C. J. T. Steenkamp and M. P. Bradley, "Active Charge/Discharge IGBT Modulator for Marx Generator and Plasma Applications," IEEE Transactions on Plasma Science, vol. 35, no. 2, pp. 473-478, Apr. 2007, doi: 10.1109/TPS.2007.892739.

[13] M. P. J. Gaudreau, T. Hawkey, J. Petry, and M. A. Kempkes, “A solid state pulsed power system for food processing," in PPPS-2001 Pulsed Power Plasma Science 2001. 28th IEEE International Conference on Plasma Science and 13th IEEE International Pulsed Power Conference. Digest of Papers (Cat. No.01CH37251), Jun. 2001, vol. 2, pp. 1174 1177 vol.2, doi: 10.1109/PPPS.2001.1001755.

[14] P. S. Brito, H. Canacsinh, J. P. Mendes, L. M. Redondo, and M. T. Pereira, "Comparison Between Monopolar and Bipolar Microsecond Range Pulsed Electric Fields in Enhancement of Apple Juice Extraction," IEEE Transactions on Plasma Science, vol. 40, no. 10, pp. 2348-2354, Oct. 2012, doi: 10.1109/TPS.2012.2209444.

[15] H. Li, H.-J. Ryoo, J.-S. Kim, G.-H. Rim, Y.-B. Kim, and J. Deng, "Development of Rectangle-Pulse Marx Generator Based on PFN," IEEE Transactions on Plasma Science, vol. 37, no. 1, pp. 190-194, Jan. 2009, doi: 10.1109/TPS.2008.2007730.

[16] W. Ding, H. Ren, Q. Zhang, and L. Yang, "Repetitive Frequency Marx Generator Based on Magnetic Switches and Its Application in Dielectric Barrier Discharge," IEEE Transactions on Plasma Science, vol. 40, no. 10, pp. 2373-2378, Oct. 2012, doi: 10.1109/TPS.2011.2174807.

[17] N. S. Pinjari, S. Bindu, and R. D. Singh, "Analysis and Comparative Study of Various Charging Methods Implemented for Solid-State Marx Generator," in Advances in Energy Research, Vol. 2, Singapore, 2020, pp. 773-785, doi: 10.1007/978-981-15-2662-6_70.

\section{AUTHORS PROFILE}

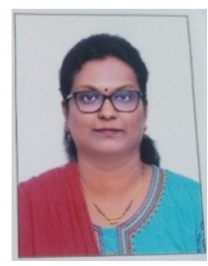

Neelam S. Pinjari received the B.E. degree in Electrical Engineering from the PVG's College of Engineering and Technology, Pune University, Pune, India, in 1999, and M.E. in Power System from Pune University in 2003. She is presently working as an Assistant Professor at Lokmanya Tilak College of Engineering, Navi Mumbai. She is currently pursuing the Ph.D. degree at Fr. C. Rodrigues Institute of Technology, Department of Electrical Engineering, Vashi, Navi-Mumbai.

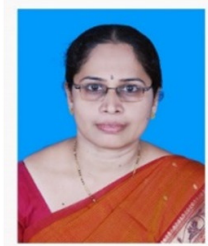

S. Bindu has received her Ph. D. degree from Veermata Jijabai Technological Institute (VJTI), Mumbai Maharashtra in 2014. She received her B. Tech. from M G Univ. Kerala and M.E in Power systems from VJTI. She is currently working as a Professor and the Head of the Department of Electrical Engineering at Fr. C. Rodrigues Institute of Technology, Vashi, Navi-
Mumbai. Her research interests include Power systems, High Voltage Engineering and HVDC. She has many research publications in International Journals, conferences and had taken up various research projects funded by the BRNS and the University of Mumbai. 